\title{
Introduction: A Tribute to David L. Nanney, An Experimental Ciliatologist
}

\author{
SALLY LYMAN ALLEN AND EDUARDO ORIAS \\ Department of Biology, University of Michigan, Ann Arbor (S.L.A.); Department of Biological Sciences, University of \\ California at Santa Barbara, Santa Barbara (E.O.)
}

In one of David Nanney's papers he gives $A$. Lwoff credit for having "persuaded Tetrahymena to eat beef" by growing it in axenic culture in 1923. Similarly one may give David Nanney the credit for having "persuaded Tetrahymena to have sex, and to tell the whole world about it."

\section{Vagn Leick \\ The University of Copenhagen}

This issue of Developmental Genetics honors David L. Nanney on the occasion of his retirement. He is the founder of Tetrahymena genetics and more than anyone has championed the ciliated protozoa as a rich source of phenomena for scientific investigation. His work has significance far beyond ciliate biology and touches on genetics, development and evolution. His legacy and impact, not only in this country but also abroad, reflect the diversity of his interests, some of which are represented in this volume. Interest in contributing to this special issue was so warm and intense that we had to a) limit the number of pages of each paper; b) focus only on researches that had a developmental genetics thrust, in some cases stretching its definition to the limit; and c) in a few other cases regretfully discourage interesting contributions (see Acknowledgments). In organizing the contents of this issue, we have attempted to recapitulate the evolution of Nanney's research interests. (A current bibliography appears at the end of this article; it includes Nanney's own papers, as well as those published by collaborators based on work conducted in his laboratory.) Articles in this issue have been grouped in sections in an order loosely described as follows: mating type and cell-cell recognition, nuclear fate and macronuclear differentiation in conjugation, genetic functions in the vegetative macronucleus, secretion, behavior, morphogenesis. Below we review, by necessity superficially, the development of Nanney's career to the present, interspersing our review with anecdotes contributed by collaborators and other scientific colleagues.

David Ledbetter Nanney is a native Virginian (born in Abingdon), but was raised in Wewoka, Oklahoma.
He attended Oklahoma Baptist University in Shawnee, Oklahoma, where he majored in English. To this day he cannot resist correcting the grammar in everything he reads. For his students, writing a thesis was a lesson in the English language as well as a scientific process. His first professional experience with biology was as a graduate student at Indiana University, where he studied genetics with Tracy Sonneborn. He quickly became immersed in the lore, life style, and mating habits of Paramecium aurelia. His researches led to publications on mating type determination in $P$. tetraurelia (a model of nucleocytoplasmic interaction) and X-ray studies on paramecin and kappa in the same species.

After receiving his $\mathrm{Ph} . \mathrm{D}$. in 1951, and marrying Jean Kelly, he took up a position at the University of Michigan, where he became a tenured Associate Professor in 1956. There he began his life-long courtship of Tetrahymena, starting with the isolation of mating types, cytological studies of conjugation, and the genetic analysis of mating type determination in variety 1 of $T$. pyriformis (a species which he and his graduate student J.W. McCoy would later name T. thermophila). In 1959 he moved to the University of Illinois, where he was promoted to full Professor. He has worked there ever since, following his Tetrahymena star, collecting new strains and species wherever he has gone and probing their genetics, development, and evolutionary relationships. Along the way he has explored macronuclear assortment and presented a model of subnuclear segregation, developed techniques and models for understanding the transmission of corticotypes, and used isozyme data and selected nucleotide sequences to determine phylogenetic relationships and the evolution of the tetrahymenids in relation to other ciliates and other organisms. Many of his ideas and concepts derived from his work are expressed in his book enti-

Received for publication November 25, 1991; accepted December 13, 1991.

Address reprint requests to Sally Allen, Department of Biology, University of Michigan, Ann Arbor, MI 48109-1048. 
tled Experimental Ciliatology, which he originally wanted to title Sex and the Single Cell. In addition, he has had a life-long interest in the sociology, philosophy, and development of science.

One of David Nanney's most quoted early observations is found in his 1953 paper in Biological Bulletin, "Nucleo-cytoplasmic interaction during conjugation in Tetrahymena." After describing the sequence of normal stages of conjugation, centrifugation was used to displace nuclei from their normal cytoplasmic site. From the abnormalities observed, he concluded that different locations in the cytoplasm had different fatedetermining activities with regard to nuclear differentiation, and that experimental alteration in the position of nuclei resulted in alterations in nuclear fate that are the essence of the nuclear dimorphism found in ciliates. These data have been particularly influential on various investigators, particularly those in France and Japan currently studying the triggers for nuclear differentiation in Paramecium.

Nucleocytoplasmic circuitry was an early theme of Nanney's work, starting with his research on mating type determination, first in $P$. tetraurelia and continuing with T. thermophila. Elegant "visual" models were designed to capture the interrelationships between systems of karyonidal and cytoplasmic inheritance in Paramecium to determine where the "homeostat" controlling a nuclear state was located. The concept of "nuclear states" was extended to the system of karyonidal inheritance seen in T. thermophila. A progressive restriction of mating type potentialities was envisioned, based on the selection of fewer competitive biochemical pathways. The original interpretation of the selfer data was that selfers are an intermediate developmental stage, having an "unstable" nuclear state in which the competition between two biochemical pathways is unresolved. The implications of the rates of "assortment" of pure mating types from selfers for a "particulate" model based on "macronuclear subunits" was appreciated when Schensted's computer simulations showed agreement with the experimental assorted numbers. This led to the hypothesis of the compound genetic nature of the macronucleus, first proposed by Sonneborn for Paramecium, and now elaborated in the context of $T$. thermophila mating type differentiation (Allen and Nanney, 1958: "An analysis of nuclear differentiation in the selfers of Tetrahymena"). This opened up a subdiscipline of its own, namely, the fundamental genetic behavior of the subunits comprising the macronucleus. Later Dave reanalyzed his mating type data in collaboration with Steve Portnoy. Having to peer review one of these papers caused Ed Orias to immerse himself in the mating type data and provided the immediate stimulus for his own later model of mating type determination, proposing DNA rearrangements during the postzygotic development of a new macronucleus.

We were there in the early years at the University of
Michigan, Ed as one of Dave's first graduate students and Sally as a "postdoc" (an unemployed spouse and nepotism victim). The atmosphere in the lab was friendly, fun, and above all philosophically challenging. Accompanied by their respective spouses, Dave and Sally toured the upper part of Michigan, spending a memorable smoke-filled night in a cabin in Wilderness State Park. David collected water samples, including a sample from a drainage ditch beside the road somewhere in Alpena, Michigan. (Later this yielded a strain of $T$. thermophila dubbed ALP-1, one of the progenitors of inbred strain D). Some of the Alpena collection contained "variety 8" (later named T. pigmentosa), which served as material for Ed's doctoral thesis on mating type determination in that species. Sally became involved in the famous "selfer" project, which Dave dubbed "Frankenstein" since her naive experimental design required 1,200 single cell isolations each day, using the old fashioned three-well depression slides (or 1,200 slides in 30 vegetable crispers). This led to the 1958 Allen-Nanney paper complemented by Irene Schensted's computer simulations using MIDAC (Michigan Digital Automatic Computer, a prehistoric mainframe computer housed in a hangar at Willow Run airport). These studies also led to Sally's abandonment of the histocompatibility locus- 2 and mouse genetics, turning down an awarded NIH grant and moving on to protozoan genetics. When Dave left Michigan in 1959, Sally inherited Dave's space.

Ed acknowledges Dave Nanney's profound influence on his life, in several fundamental aspects that include, but are not limited to, Dave's crucial contributions to his formation as a scientist. For example, Ed met his future wife, the former Judy Dodge, in a recitation section of Dave's General Genetics course. Later, Dave and Jean Nanney stood in place of Ed's parents at their wedding. Dave and Jean treated students as members of their family. Among take-home lessons from Dave that made a lasting impression, Ed remembers such statements as "A question well asked is a question half answered," or "Ideas are cheap; the limiting step is the data." Or, in response to a request for advice on a job offer from the University of California at Santa Barbara: "It's your decision; you are the one that will live with its consequences."

Coinciding with a sabbatical at the California Institute of Technology in Ray Owen's lab, Dave became interested in the immobilization antigens of Tetrahymena. Collaborating first with Jean-Marie Dubert, he turned his attention specifically to the genetics and developmental aspects of the expression of what is now known as the SerH locus. He continued working with the SerH locus when he moved to the University of Illinois. Dave's students followed up, studying the genetics and expression of serotypes T (Ruth Brosi Phillips), L (Betty Juergensmeyer), and S (Frank Grass). Peter Bruns extracted the $\mathrm{H}$ antigen as his doctoral thesis. Paul Doerder isolated and characterized muta- 
tions that regulate ser gene expression, and has continued to work on the genetics and biochemical characterization of the Ser loci. In collaboration with Dick Hallberg and Gary Bannon, a cDNA clone isolated by Duane Martindale was shown to contain a segment of the $\mathrm{SerH}$ gene and was later characterized in terms of its transcriptional and translational control. To this day Paul remains the chief "collector" among Dave's students, having isolated from nature a number of new strains which contain new SerH alleles and new Ser loci.

Examination of SerH heterozygotes quickly led to Nanney's discovery of allelic exclusion and of the general significance of macronuclear assortment in the Tetrahymena macronucleus. Moreover, the kinetics of assortment at the Ser locus were similar to that of the selfers and predicted the same number of assorting units. Differences were observed in the proportion of units expressing one or the other allele depending on which two of the four alleles were present in the heterozygote. He proposed that the assorting units were diploid subnuclei and that the macronucleus was a compound nucleus containing 45 diploid subnuclei. The implications of his hypothesis for macronuclear structure, differentiation and replication were elaborated clearly in a landmark publication in 1964 entitled "Macronuclear differentiation and subnuclear assortment in ciliates." Although a combination of later genetic and molecular work led to the idea that the assorting subunits are haploid, this paper provided a remarkably lucid view of the genetic events associated with the developing and the mature macronucleus. It also provided an intellectual framework for subsequent work by Sally Allen, Peter Bruns, Paul Doerder, Ed Orias, and their students. These genetic studies gave access to events occurring in individual macronuclei. They complement the elegant molecular approaches now being used to study the developing macronuclei, since molecular approaches generally have been based on the average properties of many developing macronuclei. Indeed, the rigorous and imaginative interpretation of genetic experiments started by Dave Nanney and carried out by him or his students over the past 30 years have provided the cornerstone for much of our current knowledge of the developing macronucleus.

According to Paul Doerder, as a Ph.D. mentor Dave Nanney was more of an advisor than a director. "He was always available, always willing to help, but rarely, if ever, domineering. He allowed the student to work at his/her own pace, and there never was pressure to obtain results for the next paper or grant application. Lab meetings consisted of critical analysis of recent papers, discussion of recent results in the lab, dissection of the latest Nanney manuscript, or (and we looked forward to these) a spontaneous lecture of the history of some problem in ciliate genetics, usually rèplete with lore about Tracy Sonneborn." Having worked as a postdoc in Dave's lab, Lea Bleyman ob- serves that "Dave is a person who loves family and he understood that one's personal life is as important as one's professional life." Indeed, dinners at the Indiana Street house or picnics at the Embarras River farm (wilderness) always included family; visits or phone calls to Dave and Jean always included exchange of news of spouses, children, grandchildren, and friends.

Dave Nanney pioneered the analysis of cortical pattern in Tetrahymena starting in the 1960s and continuing into the 1970s. Even though this work involved relatively few (but crucial) genetic crosses and no molecular analysis, the approach was thoroughly that of a geneticist. Dave started the project by analyzing cortical configurations in Tetrahymena clones that had been maintained under standard stock conditions of monthly transfer followed by growth of subclones in fresh medium for approximately 20 fissions. This method was superb for studying both variation and its inheritance. Stocks maintained under conditions of monthly transfer generated far more intraclonal variation than did stocks maintained under continuous growth, and the subcloning of these stocks allowed for evaluation of inheritance of this intraclonal variation.

Using these methods, Dave made several major discoveries. Perhaps the best known demonstrated the complementary principles of cortical inheritance and ultimate genic control as applied to the number of ciliary rows (the "corticotype"; Nanney, 1966: "Corticotypes in Tetrahymena pyriformis"). Cortical inheritance was demonstrated by the maintenance of corticotypic differences in subclones for a number of generations greater than that required for the dilution of non-replicating molecules. Ultimate genic control was suggested by the drift of the corticotype to a "stability center" at a rate inversely proportional to the initial distance from that center (Nanney, 1966: "Corticotypic transmission in Tetrahymena").

Even more impressive were the discoveries relating to cortical integration. Whereas other investigators had made inventories of variation in cortical parameters, Dave paid attention to the coordinated variation of different aspects of cortical geometry. What remains constant when many features are varying simultaneously? By asking this question, Dave made the signal discovery that the relative circumferential position of the contractile vacuole pores remains nearly constant as the number of ciliary rows changes. This led to the general conclusion, expressed in characteristic Nanney fashion, that "The concepts of fields and gradients so widely employed in a description of organismic integration in multicellular forms are equally as applicable (and equally as sterile perhaps) in a consideration of organization at the cellular level" (Nanney, 1966: "Cortical integration in Tetrahymena: An exercise in cytogeometry").

These two discoveries do not exhaust the list of major findings made by using simple approaches. Two others 
serve as excellent examples of Dave's method of studying both cortical variation and the constancy that lurks behind this variation. With regard to variation, he discovered strains that exhibited "cortical slippage", in which oral primordia appeared next to ciliary rows other than the usual right postoral ciliary row. He quickly realized that this meant that any ciliary row can potentially serve as the site of origin of an oral primordium and hence, even if there were basal body DNA, there could be no relevant genic diversification of different ciliary rows (Nanney, 1967: "Cortical slippage in Tetrahymena"). With regard to constancy, although he found that in normal Tetrahymena cells, the total number of ciliary rows varied, this number was subject to regulation, once again proving the existence of global integration in the ciliate cortex (Nanney, 1971: "The constancy of cortical units in Tetrahymena with varying numbers of ciliary rows").

To make the inventory of Dave Nanney's major discoveries concerning the cortex more complete, we would need to describe his observations on inheritance and integration of homopolar doublets as well as his comparative studies across species. Even the partial description given here shows clearly how much he achieved by technically simple observation coupled with clever quantitative analysis. He himself has reviewed much of this work in a clear and eloquent manner (Nanney, 1968: "Cortical patterns in cellular morphogenesis"; Nanney, 1972: "Cytogeometric integration in the ciliate cortex").

The person most influenced by Dave Nanney's research on the cortex is possibly Joe Frankel, although others could be mentioned: Paula Cho, Janina Kaczanowska, Andrzej Kaczanowski, and Linda Hufnagel, to name a few. Hufnagel commented that Dave's "thorough analytical approach to ciliate morphogenesis had a profound influence on her own approach to the subject". She has found it a challenge to incorporate Dave's findings and conclusions regarding morphogenesis in Tetrahymena into her own model for morphogenesis in ciliates. She also commented that she "expects to be reading and rereading Dave's papers for the rest of my life." Joe Frankel said he was stimulated and inspired by discussions with Dave in 1965 when Dave visited the University of Iowa and in 1966 at the ciliate genetics meeting at Shelter Island. Frankel started his work on spatial patterning in Tetrahymena in the Fall of 1972. He considers his own accomplishments in this area to be a continuation of the research program that Dave Nanney began. In his synthetic article in this issue "Genes and Structural Patterns in Ciliates" Vance Tartar and the "Ciliate Architects") Joe explores the connections between Tartar, Sonneborn, Beisson, Nanney and himself.

Curiosity about Tetrahymena ménages-a-trois led to an efficient way to generate cells with haploid micronuclei, and to an investigation of copy number regulation in haploid and aneuploid macronuclei. It turned out that in asymmetrically conjugating triplets, the "cell in the middle" receives migratory gametic pronuclei from both its mates and becomes triploid. However, it can only donate its migratory pronucleus to one mate; the third mate becomes haploid. This discovery led to the isolation of nullisomic Tetrahymena in Peter Bruns' lab, a unique and powerful mapping tool made possible only by the nuclear dimorphism of the ciliates. This series of investigations in Nanney's lab was done in collaboration with Rosa Maria Preparata and HansMartin Seyfert, and culminated in an insightful review in 1979, "Genetic evidence concerning the structure of Tetrahymena thermophila macronucleus."

In the early 1970's Nanney got "into" isozymes with his student Dennis Borden, Elizabeth Miller, and his isozymer colleague Greg Whitt. This work was later continued with his long-term collaborators Ellen Simon and Barbara Meyer. This work built upon the earlier work of Sally Allen on the genetics of the esterases and acid phosphatases in T. thermophila and her very modest comparisons between a few of the species in the T. pyriformis complex. By this time Nanney had amassed a considerable collection of strains representing many species of Tetrahymena. The electrophoretic pattern of various isozyme systems was compared between species and strains. The data could be used in two ways: as a diagnostic tonl to identify species and to construct phylogenetic trees. Several amicronucleate strains of Tetrahymena had lost their true identity in the course of their travels from lab to lab. These were correctly sorted out using isozyme patterns in a paper with the original title: "Will the real Tetrahymena pyriformis GL please stand up." that was published in Science in 1973 under the less dazzling title "Isozymic heterogeneity in Tetrahymena strains". Toru Higashinakagawa was able to sort out whether variation in the rDNA transcription initiation site was real or spurious as a result of Nanney's proper reclassification of strains and species by isozyme pattern. Clifford Brunk also benefitted in his work from the availability of the species collections and said: "Thanks to the Nanney lab we have a set of well-characterized species that can be easily manipulated. The Tetrahymena species are an excellent source for examination of molecular evolution, ranking with the Drosophila complexes." Critical to these studies, and to subsequent investigations of Tetrahymena genetics and evolution, was the development of methods of liquid nitrogen preservation of Tetrahymena cells by Ellen Simon in Nanney's lab.

An evolutionary thrust that began with corticotypes now bubbled forth with isozyme data and later with nucleotide comparisons of various RNA gene sequences, and remains an area of active work by Dave Nanney. A conflict in measuring genetic distances within the tetrahymenine ciliates became apparent when it was seen that the morphological data suggested closer relationships between species than did the molecular data. The rate of evolution appeared to 
be much faster for the molecules than for structures. In a witty article published in BioScience in 1982 ("Genes and phenes in Tetrahymena") Nanney concluded that molecular evolution is to a large extent uncoupled from morphological evolution in the ciliates; that is, genes and proteins continue to accumulate differences while the overall morphology of the cell and its organelles remain constrained in what is apparently a successful evolutionary strategy. These ideas have particularly influenced André Adoutte who found that this observation "remains one of the nicest demonstrations of neutral evolution and is the best available explanation for the paradox of the huge genetic differences separating sibling species in protists".

The evolutionary studies have included Craig Van Bell's postdoctoral work and have influenced Dennis Nyberg and Nicola Ricci, who are interested in the ecology as well as the evolution of ciliates. More recently Dave stimulated the development of Franco Preparata's "Phylogen" program and has applied "string analysis" to the early evolution of the eukaryotes.

Dave's passion for collecting new species of Tetrahy. mena continues to this day. Janina Kaczanowska recalls Dave's visit to Poland in 1984 and a sight-seeing trip to the area of the Mazurian lakes. "We stopped casually for awhile near a bridge. Dr. Nanney then took a vial from his pocket and quickly collected a sample of murky water and said dreamily that if there was a new species of Tetrahymena in the sample that he would name it Tetrahymena mazurka." Today there may be a Tetrahymena mazurka, although Janina is not sure if it was isolated from that particular water sample.

There is one more important area to which Dave Nanney has made a contribution: the sociology, philosophy and development of science. In recent years he has been particularly concerned with serious problems: the problems of "little science" (basic research) in a scientific world dominated by "big science," applied science, and biotechnology; the stresses placed upon science and scientists as support for science inexorably reaches a plateau; the graduation of doctoral students who are technically "trained" in a very narrow sphere rather than thinkers who can grapple with global problems; finding a way to provide creative scientists with the means and the funding necessary to pursue their serious work, however unfashionable it may be, and indeed treasuring their unorthodoxy. By example, Dave has taught us to live up to our duties and responsibilities as informed citizens of the world of science. Dave and Jean together set high ethical standards for relating to members of Dave's research group, standards that we have strived to perpetuate.

With the current preoccupation of the press and Congress over scientific fraud, Paul Doerder is reminded of what Dave has often said in the context of persuading Tetrahymena to reveal its secrets: the truth is much more interesting than anything one can make up. This characterizes Dave's approach to science. With this truth in mind, and in the name of all who, in their own way, contributed to this volume, we dedicate this special issue of Developmental Genetics to David Ledbetter Nanney.

\section{ACKNOWLEDGMENTS}

We wish to thank:

- those scientists whose proposed contributions could not be included because of topic suitability or the time limitation for submission and review: Gary Bannon, Thomas Cole, Donald Cronkite, James Forney, Richard Hallberg, Eileen Hamilton, Maria Jareno, Kathleen Karrer, Anthony Kaney, Drena Larson, Vagn Leick, David Nelson, Osamu Numata, Leif Rasmussen, and Yoshiomi Takagi. We sincerely hope that they will be publishing their papers honoring Dave Nanney in other journals.

- the many scientists that reviewed the papers that appear in this volume. Their commitment to the success of this special issue is reflected by having worked hard and with dedication, under stringent deadlines and often on short notice, but always cheerfully. The usefulness of their comments is gratefully acknowledged by us, but also was made explicit by many of the authors themselves. Their names are listed at the end of this issue (List of Reviewers).

- the many scientists who wrote letters detailing specific ways in which Dave influenced their field and their scientific lives. We are particularly indebted to Dr. Joseph Frankel for his detailed analysis of Nanney's contributions in the field of cell morphogenesis. Some of these anecdotal remarks were included in discussing Nanney's many contributions.

- the editors of Developmental Genetics, Dr. John Scandalios and Clement Markert, for their enthusiastic support of this project.

- Mr. Tony Battle, of John Wiley and Sons, for his help in turning a group of heavily "decorated" manuscripts into printed reality.

- Dr. Stephen Ng (University of Hong Kong) and Mrs. Judy Orias (University of California at Santa Barbara), who provided invaluable editorial help at critical moments.

- Ms. Debora Hall (University of Michigan), who provided critical help with formatting and in sending out the invitation to potential contributors. 


\section{DAVID L. NANNEY: A CURRENT BIBLIOGRAPHY Authored or Co-Authored papers}

Elliott AM, Nanney DL (1952): Conjugation in Tetrahymena. Science 116:33-34.

Nanney DL (1953): Mating type determination in Paramecium aurelia, a model of nucleo-cytoplasmic interaction. Proc Natl Acad Sci USA 39:113-119.

Nanney DL (1953): Nucleo-cytoplasmic interaction during conjugation in Tetrahymena. Biol Bull 105:133-148.

Nanney DL, Caughey PA (1953): Mating type determination in Tetrahymena pyriformis. Proc Natl Acad Sci USA 39:1057-1063.

Nanney DL (1954): X-ray studies on paramecins and kappas of variety 4 of Paramecium aurelia. Physiol Zool 27:79-89.

Nanney DL (1954): Mating type determination in Paramecium aurelia. A study in cellular heredity. In Wenrich DH (ed): "Sex in Microorganisms." Washington, DC: American Association for the Advancement of Science, pp 266-283.

Nanney DL, Caughey PA (1955): An unstable nuclear condition in Tetrahymena pyriformis. Genetics 40:388-398.

Nanney DL, Caughey PA, Tefankjian A (1955): The genetic control of mating type potentialities in Tetrahymena pyriformis. Genetics 40 : $668-680$.

Nanney DL (1956): Caryonidal inheritance and nuclear differentiation. Am Naturalist 90:291-307.

Nanney DL (1957): The role of cytoplasm in heredity. In McElroy WD, Glass B (eds): "The Chemical Basis of Heredity." Baltimore: Johns Hopkins Press, pp 134-163.

Nanney DL (1957): Inbreeding degeneration in Tetrahymena. Genetics $42: 137-146$

Nanney DL (1957): Mating type inheritance at conjugation in variety 4 of Paramecium aurelia. J Protozool 4:89-95.

Allen SL, Nanney DL (1958): An analysis of nuclear differentiation in the selfers of Tetrahymena. Am Naturalist 92:139-160.

Schensted IV (1958): Appendix: Model of subnuclear segregation in the macronucleus of ciliates. Am Naturalist 92:161-170.

Nanney DL (1958): Epigenetic control systems. Proc Natl Acad Sci USA 44:712-717.

Nanney DL (1958): Epigenetic factors affecting mating type expression in certain ciliates. Cold Spring Harbor Symp Quant Biol 23: $327-335$.

Nanney DL (1959): Vegetative mutants and clonal senility in Tetrahymena. J Protozool 6:171-177.

Nanney DL (1959): Genetic factors affecting mating type frequencies in variety 1 of Tetrahymena pyriformis. Genetics 44:1173-1184.

Nanney DL, Allen SL (1959): Intranuclear coordination in Tetrahymena. Physiol Zool 32:221-229.

Nanney DL (1960): Microbiology, developmental genetics and evolution. Am Naturalist 94:167-179.

Nanney DL (1960): Temperature effects on nuclear differentiation in variety 1 of Tetrahymena pyriformis. Physiol Zool 33:146-151.

Nanney DL, Dubert JM (1960): The genetics of the H serotype system in variety 1 of Tetrahymena pyriformis. Genetics 45:1335-1349.

Nanney DL (1960): The relationship between the mating type and the $\mathrm{H}$ serotype system in Tetrahymena. Genetics 45:1351-1358.

Nanney DL, Rudzinska M (1960): Protozoa. In Brachet J, Mirsky AE (eds): "The Cell." New York: Academic Pres, Vol 4, pp 109-150.

Nanney DL (1962): Anomalous serotypes in Tetrahymena. J Protozool $9: 485-487$.

Nanney DL (1963): Cytoplasmic inheritance in Protozoa. In Burdette WJ (ed): "Methodology in Basic Genetics." San Francisco: HoldenDay Inc., pp 353-378.

Nanney DL (1963): The inheritance of H-L serotype differences at conjugation in Tetrahymena. J Protozool 10:152-155.

Nanney DL (1963): Irregular genetic transmission in Tetrahymena crosses. Genetics 48:737-744.

Nanney DL, Reeve SJ, Nagel J, DePinto S (1963): H serotype differentiation in Tetrahymena. Genetics 48:803-813.

Nanney DL (1963): Aspects of mutual exclusion in Tetrahymena. In
Harris RJC (ed): "Biological Organization at the Cellular and Supercellular Levels." NY: Academic Press, pp 91-109.

Nanney DL, Nagel MJ, Touchberry RW (1964): The timing of $\mathrm{H}$ antigenic differentiation in Tetrahymena. J Exp Zool 155:25-42.

Nanney DL, Nagel MJ (1964): Nuclear misbehavior in an aberrant inbred Tetrahymena. J Protozool 11:465-473.

Nanney DL (1964): Macronuclear differentiation and subnuclear assortment in ciliates. In "The Role of Chromosomes in Development." 23rd Symp. Soc. for the Study of Dev. and Growth. Locke M (ed): NY: Academic Press, pp 253-273.

Nanney DL, Stern H (1965): "The Biology of Cells." New York: John Wiley and Sons.

Nanney DL (1966): Cortical integration in Tetrahymena: An exercise in cytogeometry. J Exp Zool 161:307-317.

Nanney DL (1966): Corticotypes in Tetrahymena pyriformis. Am Naturalist 100:303-318.

Nanney DL (1966): Corticotypic techniques in Tetrahymena taxonomy. J Protozool 13:483-490.

Nanney DL (1966): Corticotype transmission in Tetrahymena. Genetics 54:955-968.

Nanney DL (1967): Comparative corticotype analyses in Tetrahymena. J Protozool 14:553-565.

Nanney DL (1967): Cortical slippage in Tetrahymena. J Exp Zool 166: 163-169.

Nanney DL (1968): Patterns of cortical stability in Tetrahymena. J Protozool 15:109-112.

Nanney DL (1968): Ciliate genetics: Patterns and programs of gene action. Annu Rev Genet 2:121-140.

Nanney DL (1968): Cortical patterns in cellular morphogenesis. Science 160:496-502.

Nanney DL (1968): Some issues in biology teaching. BioScience 18: 104-107.

Nanney DL (1968): Biology in the future of man. Phi Kappa Phi J XLVIII 4:3-10.

Nanney DL (1970): Temperature effects on cortical characteristics of Tetrahymena. J Exp Zool 175:383-390.

Nanney DL (1971): Cortical characteristics of strains of syngens 10 , 11, and 12 of Tetrahymena pyriformis. J Protozool 18:33-37.

Nanney DL (1971): The constancy of cortical units in Tetrahymena with varying numbers of ciliary rows. $J$ Exp Zool 178:177-182.

Nanney DL (1971): The pattern of replication of cortical units in Tetrahymena. Dev Biol 26:296-305.

Nanney DL (1972): Cytogeometric integration in the ciliate cortex. Ann NY Acad Sci 193:14-28.

Nanney DL, Doerder FP (1972): Transitory heterosis in numbers of basal bodies in Tetrahymena pyriformis. Genetics 72:227-238.

Borden D, Miller ET, Nanney DL, Whitt GS (1973): The inheritance of enzyme variants for tyrosine aminotransferase, NADP dependent malate dehydrogenase, NADP dependent isocitrate dehydrogenase, and tetrazolium oxidase in Tetrahymena pyriformis, syngen 1. Genetics 74:595-603.

Borden D, Whitt GS, Nanney DL (1973): Isozymic heterogeneity in Tetrahymena strains. Science 181:279-280.

Borden D, Whitt GS, Nanney DL (1973): Electrophoretic characterization of classical Tetrahymena pyriformis strains. J Protozool 20: $693-700$.

Nanney DL, Chow M (1974): Basal body homeostasis in Tetrahymena. Am Naturalist 108:125-139.

Nanney DL (1974): Aging and long-term temporal regulation in ciliated protozoa. A critical review. Mech Ageing Dev 3:81-105.

Nanney DL (1975): Patterns of basal body addition in ciliary rows in Tetrahymena. J Cell Biol 65:503-512.

Nanney DL, Chow M, Wozencraft BS (1975): Considerations of symmetry in the cortical integration of Tetrahymena doublets. J Exp Zool 193:1-14.

Nanney DL (1976): Calcium chloride effects on nuclear development in Tetrahymena. Genet Res (Cambridge) 27:297-302.

Nanney DL, McCoy JW (1976): Characterization of the species of the Tetrahymena pyriformis complex. Trans Am Microsc Soc 95:664682 . 
Borden D, Miller ET, Whitt GS, Nanney DL (1977): Electrophoretic analysis of evolutionary relationships in Tetrahymena. Evolution 31:91-102.

Nanney DL (1977): Molecules and morphologies: The perpetuation of pattern in the ciliated protozoa. J Protozool 24:27-35.

Nanney DL (1977): Cell-cell interaction in ciliates: Evolutionary and genetic constraints. In Reisig JL (ed): "Microbial Interactions." Receptors and Recognition, Ser. B. London: Chapman \& Hall, Vol 3, pp 353-397.

Preparata RM, Nanney DL (1977): Cytogenetics of triplet conjugation in Tetrahymena: origin of haploid and triploid clones. Chromosoma 60:49-57.

Nanney DL, Meyer EB (1977): Traumatic induction of early maturity in Tetrahymena. Genetics 86:103-112.

Nanney DL, Meyer EB, Chen SS (1977): Perturbance analysis of nuclear determination in Tetrahymena. I. Background, rationale, and illustrative example, employing temperature responses. Differentiation 9:119-130

Nanney DL, Chen SS, Meyer EB (1978): Scalar constraints in Tetrahymena evolution: Quantitative basal body variations within and between species. J Cell Biol 79:727-736.

Nanney DL, Preparata RM (1979): Genetic evidence concerning the structure of the Tetrahymena thermophila macronucleus. J Protozool 26:2-9.

Simon EM, Nanney DL (1979): Germinal aging in Tetrahymena thermophila. Mech Ageing Dev 11:253-268.

Nanney DL, Meyer EB, Portnoy S (1980): Perturbance analysis of nuclear determination in Tetrahymena. Effects of nutrition, cell extracts and $\mathrm{CaCl}^{2}$ on $\mathrm{A} / \mathrm{B}$ hybrids. Differentiation $16: 49-60$.

Portnoy S, Nanney DL (1980): Perturbance analysis of nuclear determination in Tetrahymena: Analysis of mating type frequency variations with reference to binary-switch models. Differentiation 16 $61-69$.

Nanney DL, Nyberg D, Chen SS, Meyer EB (1980): Cytogeometric constraints in Tetrahymena evolution: Contractile vacuole positions in 19 species of the T. pyriformis complex. Am Naturalist 115:705717.

Nanney DL (1980): "Experimental Ciliatology: An Introduction to Genetic and Developmental Analysis in Ciliates." NY: John Wiley $\&$ Sons, pp $303+$ VIII

Nanney DL, Cooper LE, Simon EM, Whitt GS (1980): Isozymic characterization of three mating groups of Tetrahymena pyriformis complex. J Protozool 27:451-459.

Preparata RM, Doerder FP, Nanney DL (1981): Macronuclear assortment and structure in Tetrahymena thermophila: A cytogenetic approach using immunogenetic markers. In Hildemann WH (ed) "Frontiers in Immunogenetics." pp 123-140.

Nanney DL (1982): T. M. Sonneborn: An interpretation. Annu Rev Genet 15:1-9.

Nanney DL (1982): T. M. Sonneborn: Reluctant protozoologist. Acta Protozool 22:165-175.

Nanney DL (1982): Tarcy M. Sonneborn. Genetics 102:1-7.

Nanney DL (1982): Genes and phenes in Tetrahymena. BioScience $32: 783-788$.

Nanney DL (1983): The ciliates and the cytoplasm. J Hered 74:163170.

Preparata RM, Nanney DL, Simon EM (1983): The inheritance of acid phosphatase and NAD-malate dehydrogenase isozymes in Tetrahymena pigmentosa. J Hered 74:251-259.

Nanney DL (1983): Microbiology, developmental genetics and evolution. Am Naturalist 94:167-179, 1960. Reprinted in: Milkman R (ed): "Benchmark Papers in Population Genetics."

Nanney DL (1984): The molecular diversity and evolutionary antiquity of the Tetrahymena pyriformis species complex. In "Progress in Protozoology." Acta Protozool, Special Congress Volume, Part II 243-266.

Simon EM, Nanney DL (1984): Karyonidal inheritance of mating types in Tetrahymena malccensis. Dev Genet 5:43-58.

Nanney DL (1984): Microbial precursors of developmental processes. Verh Dtsch Zool Ges 77:7-17.
Nanney DL (1985): The tangled tempos underlying Tetrahymena taxonomy. Atti Soc Tose Sci Natur Mem Ser B 92:1-13.

Nanney DL (1985): Heredity without genes: The ciliate explorations. Trends Genet 1:295-298.

Nanney DL (1986); Chapter 1. Introduction. In Gall JG (ed): "The Molecular Biology of Ciliated Protozoa." NY: Academic Press, pp $1-26$

Nanney DL (1986): Documenting eugenics and human genetics. J Hered 77:287-288.

Meyer EB, Nanney DL (1987): Isozymes in the ciliated protozoan Tetrahymena. In "Isozymes." Curr Top Biol Med Res 13:61-101.

Nanney DL (1988): Expectations and realities in academic biology. Bioscience 38:344-348.

Nanney DL, Preparata RM, Preparata FP, Meyer EB, Simon EM (1989): Shifting ditypic site analysis: heuristics for expanding the phylogenetic range of nucleotide sequences. J Mol Evol 28:451-459.

Preparata RM, Meyer EB, Preparata FP, Simon EM, Vossbrinck CR, Nanney DL (1989): Ciliate evolution: The ribosomal phylogenies of the tetrahymenine ciliates. J Mol Evol 28:427-441.

Nanney DL, Meyer EB, Simon EM, Preparata RM (1989): Comparison of ribosomal and isozymic phylogenies of tetrahymenine ciliates. J Protozool 36:1-8.

Nanney DL (1989): What can molecules tell us about evolution? Boll Zool 56:205-221.

Nanney DL, Mobley DO, Preparata RM, Meyer EB, Simon EM (1991): Eukaryotic origins: String analysis of $5 \mathrm{~S}$ ribosomal RNA sequences from some relevant organisms. J Mol Evol 32:316-327.

Nanney DL (1991): Book review. In Frankel J (ed): "Pattern Formation: Ciliate Studies and Models." Trends Genet 7:66-67.

Beam CR, Preparata RM, Himes M, Nanney DL (1991): A ribosomal phylogeny for the dinoflagellate sibling species swarm of Crypthecodinium cohnii. J Protozool (submitted).

Preparata RM, Beam CA, Himes M, Nanney DL, Meyer EB, Simon EM (1991): Crypthecodinium and Tetrahymena: An exercise in comparative evolution. J Mol Evol (in press).

\section{Work Not Co-Authored, but Done at Least in Part in His Lab and Supported at Least in Part by His Grant}

Orias E (1960): The genetic control of two lethal traits in variety 1 , Tetrahymena pyriformis. J Protozool 7:64-69.

Orias E (1963): Mating type determination in variety 8 , Tetrahymena pyriformis. Genetics 48:1509 -1518.

Bleyman LK, Simon EM, Brosi R (1966): Sequential nuclear differentiation in Tetrahymena. Genetics 54:277-291.

Bleyman LK, Simon EM (1967): Genetic control of maturity in Tetrahymena pyriformis. Genet Res (Cambridge) 10:319-321.

Simon EM, Hwang S (1967): Tetrahymena: Effect of freezing and subsequent thawing on breeding performance. Science 155:694-696.

Phillips RB (1967): Inheritance of T serotypes in Tetrahymena. Genetics 56:667-681.

Phillips RB (1967): T serotype differentiation in Tetrahymena. Genetics 56:683-692.

Phillips RB (1968): Mating type alleles in Illinois strains of Tetrahymena pyriformis, syngen 1. Genet Res (Cambridge) 11:211-214.

Klug SH (1968): Cortical studies on Glaucoma. J Protozool 15:321327.

Bleyman LK, Simon EM (1968): Clonal analysis of nuclear differentiation in Tetrahymena. Dev Biol 18:217-231.

Juergensmeyer E (1969): Serotype expression and transformation in Tetrahymena pyriformis. J Protozool 16:344-352.

Phillips RB, Abraham I (1969): Mating type inheritance in Glaucoma. J Protozool 16:375-377.

Phillips RB (1969): Mating type inheritance in syngen 7 of Tetrahymena pyriformis: Intra- and interallelic interactions. Genetics 63 : 349-359.

Cho PL (1971): Cortical patterns in two syngens of Glaucoma. J Protozool 18:180-183. 
Cho PL (1971): The genetics of mating type in a syngen of Glaucoma. Genetics 67:377-390.

Phillips RB (1971): Inheritance of immobilization antigens in syngen 7 of Tetrahymena pyriformis: Absence of phenotypic assortment in heterozygotes. Genetics 67:391-398.

Phillips RB (1971): Induction of competence for mating in Tetrahymena by cell-free fluids. J Protozool 18:163-165.

Bruns PJ (1971): Immobilization antigens of Tetrahymena pyriformis. I. Assay and extraction. Exp Cell Res 65:445-453.

Bleyman LK (1971): Temporal patterns in the ciliated protozoa. In Cameron IL, Padilla GM, Zimmerman AM (eds): "Developmental Aspects of the Cell Cycle." NY: Academic Press, pp 67-91.

Simon EM (1971): Paramecium aurelia: Recovery from -196C. Cryobiology 8:361-365.

Grass FS (1972): Geneties of the St serotype system in Tetrahymena pyriformis, syngen 1 . Genetics 70:521-536.

Grass FS (1972): An immobilization antigen in Tetrahymena pyriformis expressed under conditions of high salt stress. J Protozool 19:505-511.

Phillips RB (1972): Similar times of differentiation of acid phosphatase heterozygotes in two syngens of Tetrahymena pyriformis. Dev Biol 29:65-72.

McCoy JW (1972): Kinetic studies on the mating reaction of Tetrahymena pyriformis, syngen 1. J Exp Zool 180:271-278.

Simon EM (1972): Freezing and storage in liquid nitrogen of axenically and monoxenically cultivated Tetrahymena pyriformis. Cryobiology 9:75-81.

Perlman BS (1973): Temperature effects on maturity periods in Tetrahymena pyriformis. J Protozool 20:106-107.

Perlman BS (1973): Basal body addition in ciliary rows of Tetrahymena pyriformis. J Exp Zool 184:365-368.

Doerder FP (1973): Regulatory serotype mutations in Tetrahymena pyriformis, syngen 1. Genetics '14:81-106.

McCoy JW (1973): A temperature-sensitive mutant in Tetrahymena pyriformis, syngen 1 . Genetics 74:107-114.

Simon EM, Schneller MV (1973): The preservation of ciliated protozoa at low temperature. Cryobiology 10:421-426.

McCoy JW (1974): Biology and systematics of the ciliate genus Cyrtolophosis, Stokes, 1885. Acta Protozool 13:41-52.

McCay JW (1974): New features of the tetrahymenid cortex revealed by protargol staining. Acta Protozool 13:155-160.

McCoy JW (1974): Updating the Tetrahymenids. I. General considerations and application to the genus Colpidium. Acta Protozool 13: 161-176.

Nyberg D (1974): Breeding systems and resistance to environmental stress in ciliates. Evolution 28:367-380.

Simon EM (1974): The preservation of ciliated protozoa in liquid nitrogen. In "Symposium on Freeze-Drying of Biological Materials." I.I.F.-I.I.R. Commission C1-Sapporo 1973-5:103-108.

Simon EM, Flacks M (1975): Preparation, storage and recovery of free-living, non-encysting protozoa. In Rinfret AP, LaSalle B (eds): "Round Table Conference on the Cryogenic Preservation of Cell Cultures." USA: National Academy of Science, pp 37-49.

Kaczanowski A (1975): A single gene dependent abnormality of adoral membranelles in syngen 1, Tetrahymena pyriformis (Ciliates). Genetics 81:631-639.

Weindruch RH, Doerder FP (1975): Age dependent micronuclear deterioration in Tetrahymena pyriformis, syngen 1. Mech Ageing Dev $4: 263-279$
McCoy JW (1975): Updating the Tetrahymenids. II. Domestic and natural variation of amicronucleate species of the Tetrahymena pyriformis complex. Acta Protozool 13:235-243.

McCoy JW (1975): Updating the Tetrahymenids. IV. Cortical properties of Glaucoma. Protistologica 11:149-158.

Kaczanowski A (1976): An analysis of mp gene affected morphogenesis in Tetrahymena pyriformis, syngen 1 (Ciliates). J Exp Zool 196:215-230.

McCoy JW (1976): Updating the Tetrahymenids. III. Natural variation in Tetrahymena setosa nov. comb. Acta Protozool 14:253-262

Kaczanowski A (1978): Gradients of proliferation of ciliary basal bodies and determination of the position of the oral primordium in Tetrahymena. J Exp Zool 204:417-430.

Seyfert HM, Preparata RM (1979): The regulation of amounts and proportions of genetic elements in the macronuclei of Tetrahymena thermophila strains of diverse karotype. J Cell Sci 40:111-123.

Simon EM (1980): Mating type inheritance and maturity times in crosses between subspecies of Tetrahymena pigmentosa. Genetics 94:93-113.

Seyfert HM, Willis JH (1981): Molecular polymorphism of ciliary proteins from different species of the ciliate Tetrahymena. Biochem Genet 19:385-396.

Miller AR (1981): A computer model of the evolution of specific maximum lifespan. Mech Ageing Dev 16:37-54.

Ricci N (1981): Ionic resistance in strains of the Tetrahymena pyriformis complex. J Protozool 28:453-460.

Simon EM, Doerder FP (1981): The unique position of the degenerating macronucleus in Tetrahymena tropicalis. J Protozool 28:203205.

Doerder FP (1982): Differential expression of immobilization antigen genes in Tetrahymena thermophila. II. Reciprocal and non-reciprocal transfer of i-antigen during conjugation and expression of $\mathrm{i}$ antigen genes during macronuclear develnnment. Cell Differ 10: $299-307$.

Simon EM (1982): Breeding performance of Tetrahymena thermophila following storage for 5 to 6 years in liquid nitrogen. Cryobiology 19:607-612.

Nielsen H, Simon EM, Engberg J (1985): Updating rDNA restriction enzyme maps of Tetrahymena reveals four new intron-containing species. J Protozool 32:480-485.

Simon EM, Meyer EB, Preparata RM (1985): New wild Tetrahymena from Southeast Asia, China, and North America, including T. malaccensis, T. asiatica, T. nanneyi, $T$. caudata, and $T$. silvana n. spp. J Protozool 32:183-189.

Van Bell CT (1985): The 5S and 5.8S ribosomal RNA sequences of Tetrahymena thermophila and T. pyriformis. J Protozool 32:640644.

Simon EM, Orias E (1987): Genetic instability in the mating type system of Tetrahymena pigmentosa. Genetics 117:437-449.

Gaertig J, Kaczanowski A (1987): Correlation between the shortened period of cell pairing during genomic exclusion and the block in posttransfer nuclear development in Tetrahymena. Dev Growth Differ 29:553-562.

Kaczanowski A, Gornicka I, Cleffmann G (1989): Arrest of micronuclear DNA replication during genomic exclusion in Tetrahymena produces haploid strains. Genetics 121:37-45.

Nielsen H, Simon EM, Engberg J (1991): Inheritance of the ribosomal intron in Tetrahymena pigmentosa. Dev Genet (this issue).

Simon EM, Meyer EB (1991): Suicide is not the inevitable outcome of "perpetual" selfing in Tetrahymenines collected from natural habitats. Dev Genet (this issue) 